\title{
Dynamics of Elaeis guineensis Jacq. Agroforestry Parklands in the Region of Cacheu (Guinea Bissau) from 2003 to 2018
}

\author{
Boubacar Sagna ${ }^{1,3,}$, Daouda Ngom ${ }^{2}$, Boubacar Camara ${ }^{1}$, Mamadou Abdoul Ader Diedhiou ${ }^{1}$, \\ Boubacar Solly ${ }^{4}$, Sekouna Diatta ${ }^{2}$
}

${ }^{1}$ Department of Agroforestry, Assane SECK University of Ziguinchor, Ziguinchor, Senegal

${ }^{2}$ Department of Vegetable Biology, Cheikh Anta Diop University, Dakar, Senegal

${ }^{3}$ Research and Development Group for Rural Development (Grdr), Cacheu, Guinea Bissau

${ }^{4}$ Department of Geography, Assane SECK University of Ziguinchor, Ziguinchor, Senegal

Email address:

boubacarsagna22@gmail.com (B. Sagna), daoudangom52@gmail.com (D. Ngom), Camarabouba2@gmail.com (B. Camara), Abdoulader28@gmail.com (M. A. A. Diedhiou),bakisolly@hotmail.com (B. Solly), seckouna.diatta@ucad.edu.sn (S. Diatta)

${ }^{*}$ Corresponding author

\section{To cite this article:}

Boubacar Sagna, Daouda Ngom, Boubacar Camara, Mamadou Abdoul Ader Diedhiou, Boubacar Solly, Sekouna Diatta. Dynamics of Elaeis guineensis Jacq. Agroforestry Parklands in the Region of Cacheu (Guinea Bissau) from 2003 to 2018. American Journal of Agriculture and Forestry. Vol. 9, No. 5, 2021, pp. 299-311. doi: 10.11648/j.ajaf.20210905.14

Received: August 27, 2021; Accepted: September 14, 2021; Published: October 12, 2021

\begin{abstract}
Like other regions of Guinea Bissau, the economy of the Cacheu region is not very diversified and is dominated by cashew nut cultivation. As the country's leading production zone, with more than $30 \%$ of the national cashew nut production, the region has seen the disappearance of a large part of its natural ecosystems, especially the Elaeis guineensis parklands, despite their socio-economic importance. It is in this logic that this study is devoted to the analysis of the dynamics of the Elaeis guineensis parklands in the Cacheu region over the last fifteen years. To do this, terroir transects and mapping were carried out in order to identify and see the evolution of the landscape units. Surveys on the dynamics of the parklands and other landscape units have been carried out. The combination of these methods revealed a strong disappearance of Elaeis guineensis parklands and natural vegetation. Between 2003 and 2018, an average increase of 224 ha of cashew plantation by village terroir was noted, already causing the disappearance of 153.26 ha of Elaeis guineensis parklands on average. The main cause of this disappearance is the uncontrolled expansion of cashew nut plantations. In addition to this, there are many cuts of palm tree for house construction, habitat expansion, bad exploitation practices and climate deterioration. This pressure on Elaeis guineensis parklands is gradually leading them to disappear in favour of cashew nut monoculture. It is for this purpose that special attention is being paid to these ecosystems, which are of paramount importance to the livelihood of the local population.
\end{abstract}

Keywords: Elaeis guineensis, Guinea Bissau, Cashew Nut, Agroforestry Parklands, Ecosystems

\section{Introduction}

As in most sub-Saharan African countries, Guinea-Bissau's economy is essentially based on the primary sector dominated by agriculture [1]. This sector is still very undiversified in the country and is largely dominated by the cultivation of Anacardium occidentale L. or cashew nuts. Indeed, more than $90 \%$ of the population of Guinea-Bissau depends directly on cashew nuts. It accounts for $90 \%$ of export earnings, $18 \%$ of GDP, $85 \%$ of direct and indirect employment and $33 \%$ of household income $[12,9]$. This high cashew nut production is the result of a major transformation of natural ecosystems, especially in the Cacheu region, which is by far the country's leading production area, accounting for more than $30 \%$ of the national total. This region abounds in important natural palm groves commonly known as Elaeis guineensis Jacq. parklands. The exploitation of these 
parklands, particularly for the production of palm oil, palm wine and other by-products, is very important in the economy of the region as it generates financial resources for the benefit of local communities [15]. Apart from its economic value, palm oil from Elaeis guineensis Jacq has nutritional and/or medicinal values due to its contribution in vitamins $\mathrm{A}$ and $\mathrm{E}$.

Despite their cultural/cultural, ecological and socioeconomic importance, the Elaeis guineensis parklands of the region are not spared by the conversion of natural areas to cashew nut plantations, encouraged by a land tenure system that encourages a race to monoculture cashew nut as a land marker tree [18]. To this end, this study aims to analyze the dynamics of Elaeis guineensis parklands in the Cacheu region over the last fifteen (15) years.

\section{Methodological Approach}

\subsection{Presentation of the Study Area}

Cacheu is one of the eight regions of Guinea Bissau. Located in the North-West of the country, the Cacheu region is bordered to the East by the Oio region, to the North by Senegal with the Casamance region, to the South by the Biombo region, to the West by the opening on the Atlantic Ocean and a coastline of $350 \mathrm{~km}$. This region has more than 185,000 inhabitants and covers an area of $5,175 \mathrm{~km}^{2}$. It is thus the fourth largest region in the country. Administratively, the region is currently divided into six sectors: Bigene, Bula, Cacheu/Calequisse, Caio, Canchungo and São Domingos (Figure 1).

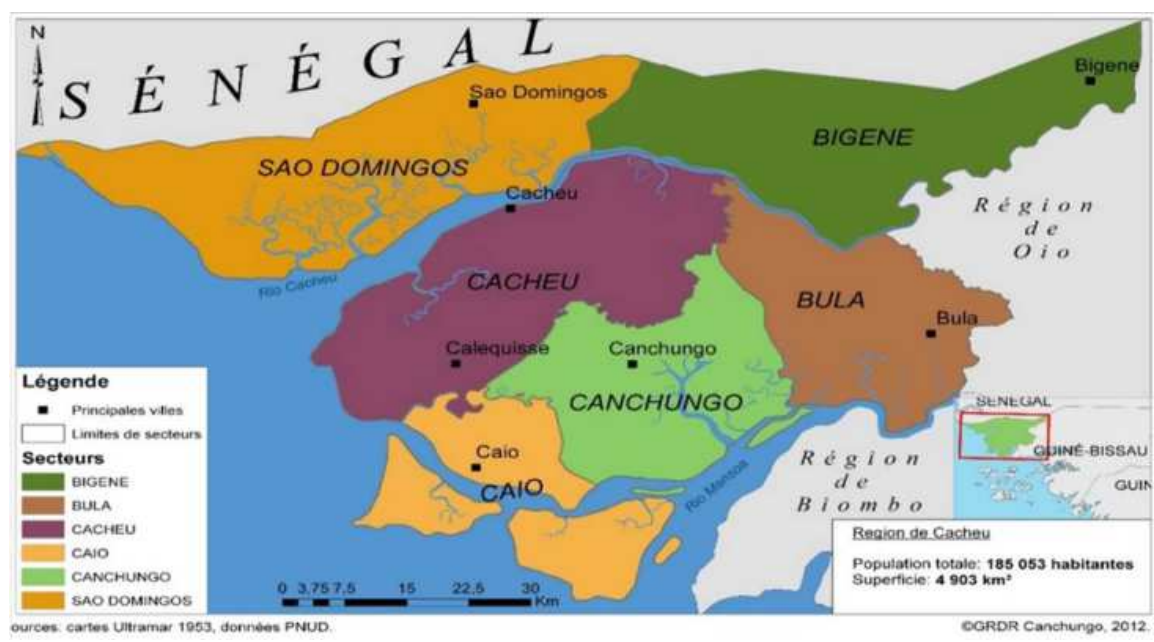

Figure 1. Administrative Subdivision of the Cacheu Region.

The climate of the Cacheu region is characterized by two main annual seasons: the rainy season which runs from June to October with a southwest wind; and the dry season which runs from November to May with the harmattan, or dry wind from the northeast. The annual rainfall average calculated over the last five decades (from 1967 to 2017) is $1443 \mathrm{~mm}$. This average rainfall varies from year to year. The following figure shows the variation in average rainfall, taken at the level of the six sectors of the region, from 1967 to 2017.

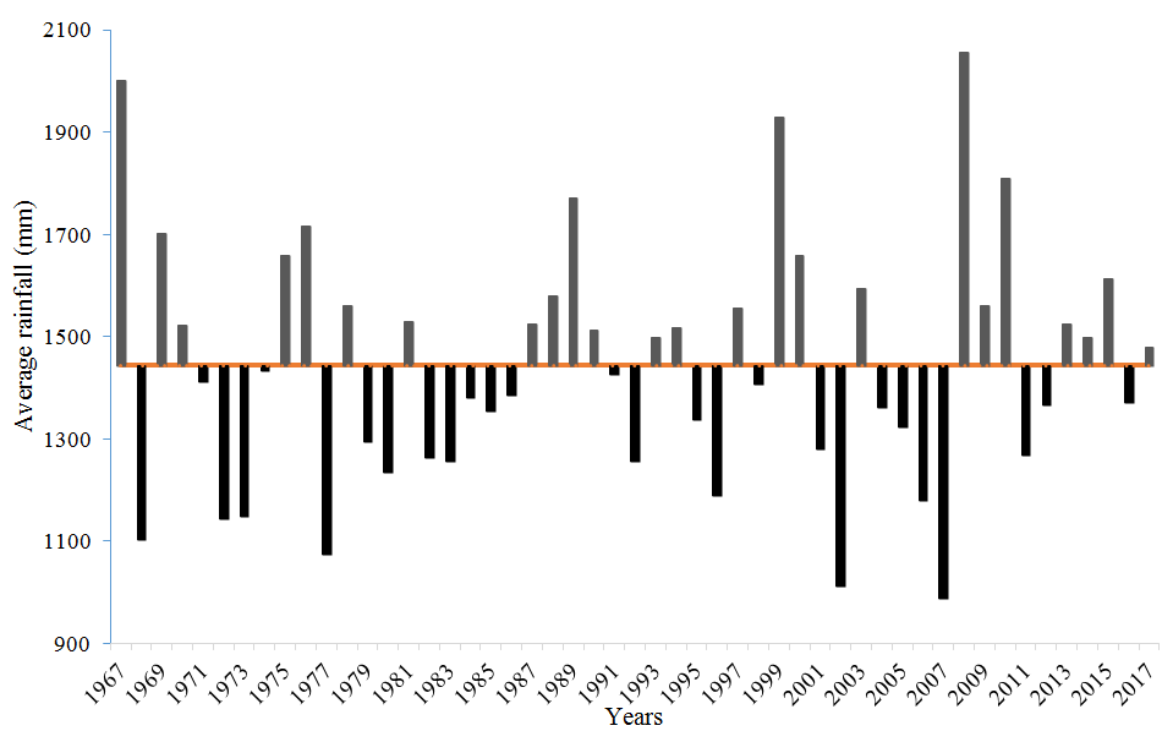

Figure 2. Change in annual rainfall average in the Cacheu region from 1967 to 2017 (Data source. National Institute of Meteorology, 2018). 
Temperatures oscillate between $25.5^{\circ} \mathrm{C}$ and $32.9^{\circ} \mathrm{C}$ with an average of $26.6^{\circ} \mathrm{C}$ and a humidity level of over $65 \%$. The rate of evapotranspiration in this agro-ecological zone is quite high and estimated at $1190 \mathrm{~mm} / \mathrm{year}$ between June and October (source: National Institute of Meteorology, 2018).

With its watershed covering $1,722 \mathrm{~km}^{2}$, the Cacheu region has enormous water potential. The considerable hydrographic network of the Cacheu region is mainly based on the Rio Cacheu river system, which is one of the main rivers of Guinea Bissau flowing into the Atlantic Ocean.

The Cacheu region contains various types of more or less forested plant formations. The forest formations occupy a total area of 261,600 ha, including 41,200 ha of palm groves, i.e. $15.74 \%$ of the forest area. The remainder is mainly composed of open forest (13.30\%), savannah $(36.08 \%)$, mangrove $(34.70 \%)$ and riparian forest $(0.15 \%)$ [17].

Two types of materials were used in this study. These are aerial images for mapping changes in land use and parklands in Elaeis guineensis, and field equipment.

The aerial images used are captured from Google Earth Pro. They were acquired in 2003 (26/04/2003 - 18/02/2003) and in $2018(10 / 11 / 2018)$. To cover certain village terroirs, the $2019(08 / 06 / 2019)$ image was used in the absence of the 2018 image. The choice of these images is linked to their very high resolution which can go up to $1 \mathrm{~m}$. This resolution seems to us sufficient for the needs of this study. In addition, the images are accessible. The dates on which the images were taken are subject to availability. The 2003 image allows us to see the oldest situation from what Google Earth pro offers in the area studied. The image of 2018 or, failing that, the image of 2019 allows to see the current state of land use.

The field equipment is composed of a Garmin eTrex 30x GPS for taking geographic coordinates, an ixus 145 gun camera for taking pictures, an elaborate sheet for identifying landscape units and a smartphone for collecting survey data.

\subsection{Methods}

\subsubsection{Transects of Terroir}

In order to determine the landscape profile of village terroirs, a terroir transect, which is a territorial diagnostic tool, was carried out in all 6 study sites out of the 14 selected in the region (Figure 3). It also made it possible to identify the activities carried out in each landscape unit, to determine the soil properties and significant changes in each zone. The terroir transect is a tool of the active participatory research Method (MARP) which is based on direct observation and following a straight line by walking from one end of the terroir to the other. It is defined as "a field observation device or the representation of a space, along a linear path and according to the vertical dimension, intended to highlight a superposition, spatial succession or relationships between phenomena" $[19,20]$. The transects were carried out in the company of a mixed group of indigenous people composed of men, women, old people, adults and young people.

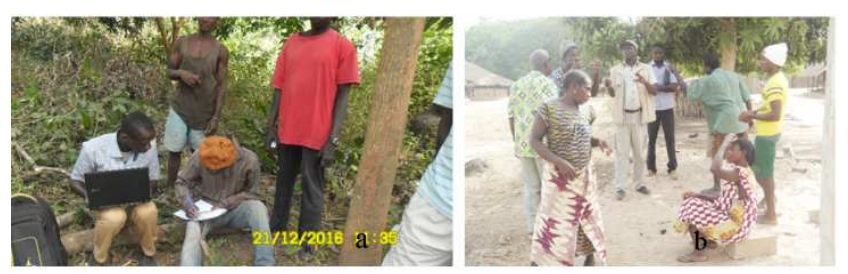

Figure 3. Photos of the village land transect teams: (a) in Mpakaque, (b) in Ponta campo.

\subsubsection{Mapping of the Elaeis guineensis Parklands Evolution and Other Land Use Classes}

The mapping protocol is essentially structured around five stages: georeferencing, photo-interpretation, field work and development of the final legend, digitization, verification and validation. It is based on a number of studies $[16,5,3]$.

Georeferencing consisted of giving geographic coordinates to the images through georeferencing by integration from Google Earth. It required a prior definition of the geographic coordinate system (UTM, WGS 84, Zone 28N) on Arc Gis 10.5 and then finding the same remarkable points both on the images used and on Google Earth Pro.

Following georeferencing, a visual interpretation of the images is carried out. This step allowed the identification of land use elements and their spatial distribution. The approach consisted in visually interpreting the images, classifying them and assessing their spatial and temporal distribution and evolution. The interpretation was based on the image descriptors of colour, shape and hue. This step made it possible to identify the different classes of land use.

In order to verify and validate the thematic classes identified by photo-interpretation and to collect GPS points to be used for the validation of land use maps, an identification mission was carried out in all the sites in the study area. This mission made it possible to define, for all the village terroirs, a definitive legend of nine thematic classes, which are: Anacardium occidentale Orchard, Elaeis guineensis Parkland, Elaeis-Anacardium Mosaic, Other Vegetation, Habitat, Growing Area, Mangrove, Tanne and Watercourses. On each of these thematic classes thus identified, a minimum of 5 GPS points were surveyed in the field in each terroir for the purposes of map validation. Once the thematic classes were selected, a file of vectorial shapes (polygons) delimiting the village terroirs was first created using the Arc GIS software Arc Catalogue tool. Then, the classes are digitized on the screen according to colour, object shape and hue. Validation of the results was done using GPS points taken on each of the classes in the field and in each terroir for the most recent year and by interpolation for previous years.

\subsubsection{Surveys}

In order to gain a better understanding of the factors influencing the evolution of the different landscape units in the Cacheu region in general, and the Elaeis guineensis parklands in particular, surveys were carried out in the 
fourteen villagers studied. Two tools were used. These are the individual questionnaire and the interview guides. The questionnaire is coded directly on a smartphone through the KoboCollect application. The sampling method used is simple random sampling with no discount. In each of the localities selected for the mapping, 5\% of the active population was interviewed through the questionnaire. The minimum age of the respondents was set at 25 years because at this age, the respondent will have a fairly broad vision of the evolution of the surface area and production of the parklands and other landscape units. The guides were conducted in the form of focus groups in all 14 villages. Thus, 14 focus groups were conducted throughout the entire region, one per village.

\section{Results}

\subsection{Landscape Profile of the Village Terroirs of the Cacheu Region}

The terroir transects carried out at the various sites made it possible to identify a certain number of landscape units distributed according to toposequence and to determine the landscape profile of the village terroirs in the region. The distribution of the main units according to toposequence is shown in the following table.

Table 1. Landscape profile of village terroirs according to toposequence.

\begin{tabular}{|c|c|c|c|c|c|}
\hline $\begin{array}{l}\text { Name of the landscape } \\
\text { unit: English and Creole }\end{array}$ & $\begin{array}{l}\text { Plateau area } \\
\text { Mato }\end{array}$ & $\begin{array}{l}\text { Habitation area } \\
\text { Morança }\end{array}$ & $\begin{array}{l}\text { Transition zone } \\
\text { Riada }\end{array}$ & $\begin{array}{l}\text { Lowland zone } \\
\text { Boulanha }\end{array}$ & $\begin{array}{l}\text { Mangrove zone } \\
\text { Tarefas }\end{array}$ \\
\hline Soil type: English and & Sandy loamy & Sandy loamy & Sandy- Clayey & Clayey & Muddy \\
\hline Creole & Reia (créole) & Reia (créole) & Reia (créole) & Lama de boulanha & Lama \\
\hline Soil properties & $\begin{array}{l}\text { fertile, blackish permeable, } \\
\text { favourable for } \\
\text { arboriculture }\end{array}$ & $\begin{array}{l}\text { Moderately fertile, } \\
\text { reddish permeable, } \\
\text { suitable for } \\
\text { arboriculture, }\end{array}$ & $\begin{array}{l}\text { fertile, moderately } \\
\text { permeable, grey } \\
\text { favourable for rain-fed } \\
\text { agriculture }\end{array}$ & $\begin{array}{l}\text { Very fertile, } \\
\text { impermeable, grey, } \\
\text { suitable for rice } \\
\text { growing. }\end{array}$ & $\begin{array}{l}\text { fertile, impermeable, } \\
\text { grey, conducive to } \\
\text { mangrove development }\end{array}$ \\
\hline Socio-economic activities & $\begin{array}{l}\text { cashew cultivation, oil } \\
\text { palm farming, rain-fed } \\
\text { agriculture }\end{array}$ & $\begin{array}{l}\text { Food crops, } \\
\text { Vegetable growing, } \\
\text { Cashew cultivation, } \\
\text { Animal husbandry }\end{array}$ & $\begin{array}{l}\text { Oil palm farming, cashew } \\
\text { cultivation, vegetable } \\
\text { production, rain-fed } \\
\text { agriculture }\end{array}$ & $\begin{array}{l}\text { Rice farming, salt } \\
\text { farming, } \\
\text { Straw farming }\end{array}$ & $\begin{array}{l}\text { Fishing, mangrove } \\
\text { logging, Mangrove rice } \\
\text { cultivation }\end{array}$ \\
\hline $\begin{array}{l}\text { Occupation in the young of } \\
\text { the accompanying persons }\end{array}$ & $\begin{array}{l}\text { Natural forest, palm groves } \\
\text { and cultivation area. }\end{array}$ & $\begin{array}{l}\text { Habitation, } \\
\text { cultivation area }\end{array}$ & $\begin{array}{l}\text { Natural forest, palm groves } \\
\text { and cultivation area }\end{array}$ & $\begin{array}{l}\text { Cultivation of rice } \\
\text { and tannins }\end{array}$ & Mangroves and rivers \\
\hline Causes of land use changes & \multicolumn{3}{|c|}{$\begin{array}{l}\text { Strong conversion of natural areas for the introduction of Cashew cultivation } \\
\text { from the } 1980 \text { s onwards }\end{array}$} & No change & \\
\hline
\end{tabular}

The plateau area: The Cashew Plantation is the landscape unit that populates almost the entire plateau area. Rainfed agriculture is little carried out in this zone because of the strong aerial cover of cashew trees, except in the young plantations where a mixture of Anacardium and Elaeis is found. The main activities carried out in the upland zone are cashew nut and oil palm exploitation. This area has very little natural vegetation due to the development of cashew nut cultivation in the region.

The residential area: this is the area devoted to buildings. There are also cashew nut orchards between the houses and the main activities carried out there are food crops, market gardening, cashew nut exploitation, palm oil production and domestic animal husbandry.

The transition zone or slope: this is the area between the houses and the lowlands. It is the zone marked by a strong presence of palm groves. However, this zone is undergoing strong change due to anthropic pressure. Indeed, it is being transformed into a cashew plantation. The main activities carried out in the transition zone are oil palm exploitation, cashew nut exploitation, market gardening and rainfed agriculture.

Enormous changes have been reported at the level of the landscape units by the companions compared to their youth. Indeed, the major changes observed in all the above- mentioned areas concern the intense process of conversion of natural areas for the introduction of cashew nut cultivation. This process was accentuated from the 1980s onwards. The only areas that have not undergone major changes are the lowland and mangrove areas for the sole reason that they are not conducive to the development of cashew trees.

The lowland zone: this is the rice and salt-growing zone. It is also the zone where straw is used to cover houses. Given the problem of access to upland land and the proximity of the water table, the zone is often coveted by women for market garden production in the dry season.

The mangrove zone: this is the area where mangroves and other marine species occupy the area. The main activities carried out in the mangrove zone are fishing and the exploitation of other mangrove products (wood, oysters, crabs, etc.). It is also the place where mangrove rice is produced.

\subsection{Elaeis guineensis Parkland Dynamics in the Cacheu Region}

The surveys conducted in the 14 villages made it possible to evaluate the perception of the populations on the evolution of the surface area and density of the Elaeis guineensis parklands in their territory. The results obtained are shown in the following figure. 


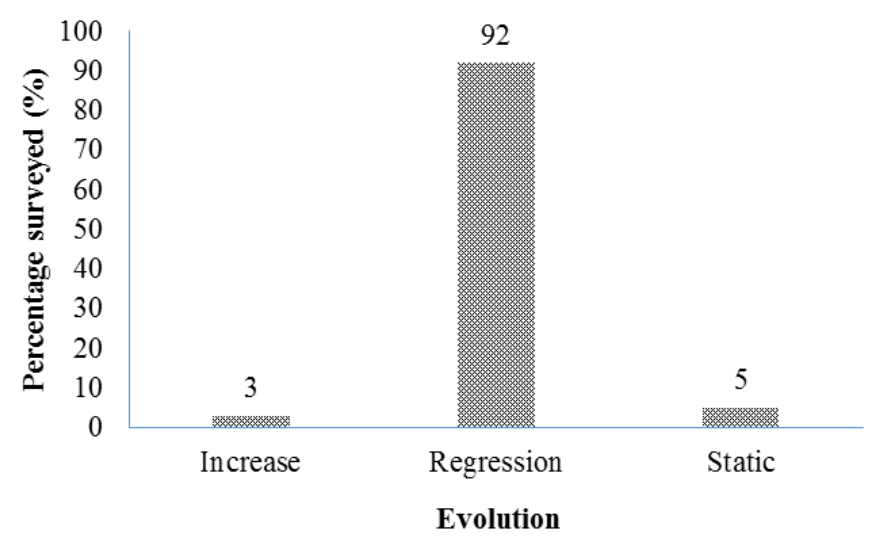

Figure 4. Evolution of surface areas and density in Elaeis guineensis parklands.

Generally speaking, the Elaeis guineensis parklands of the Cacheu region are undergoing a regressive evolution. Indeed $92 \%$ of the people surveyed attest that the parklands have experienced a strong regression in terms of area and density. These assertions have been verified through mapping work carried out in order to evaluate the dynamics of the Elaeis guineensis parklands as well as other representative landscape units in each of the sites. The results obtained are recorded in the following series of figures.

The analysis of figure 5 shows that there is a strong modification of the landscape units in the village terroir of Ponta Compo. This is marked by a strong increase in the area occupied by Anacardium occidentale plantations to the detriment of the other classes. The statistical results of the evolution of the landscape units in the zone are shown in the following figure.

\section{Evolution of the landscape units of the Ponta Campo village terroir}

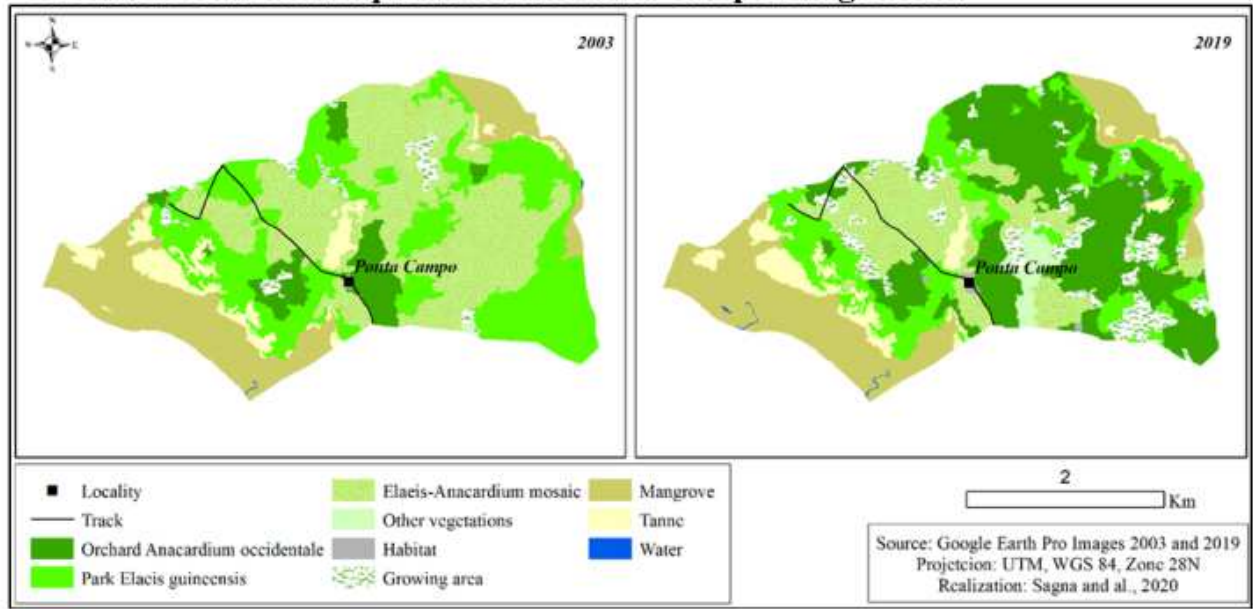

Figure 5. Cartography of the evolution of the landscape units of the village terroir of Ponta Campo.

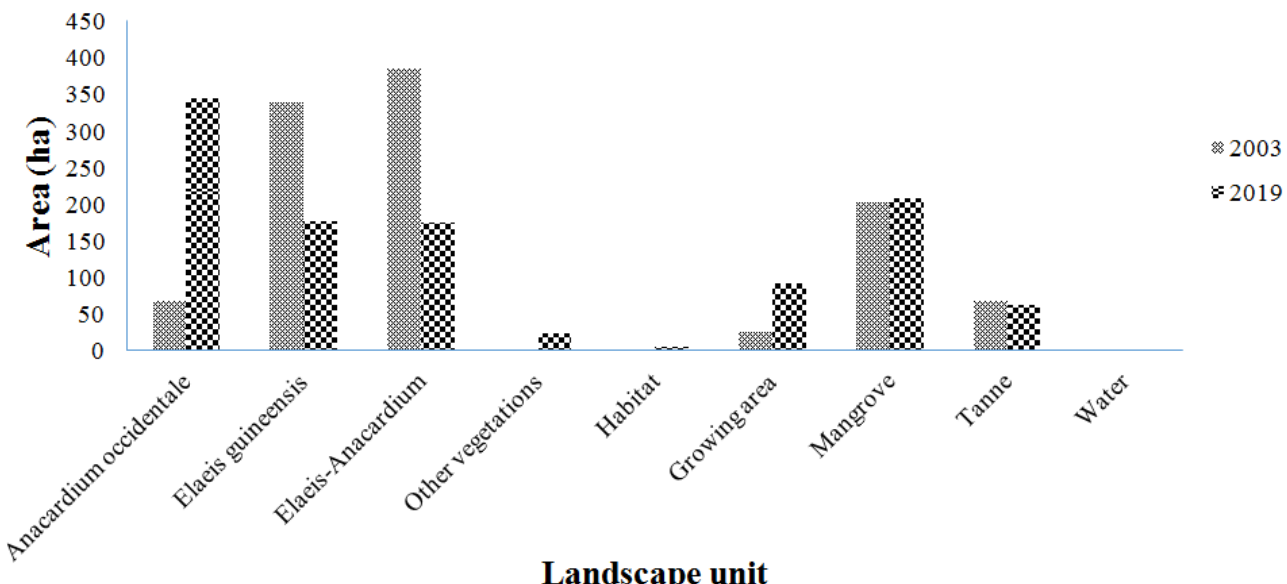

\section{Landscape unit}

Figure 6. Evolution of the surface areas of the landscape units of the Ponta Campo village terroir between 2003 and 2019. 
In 2003, the village land was mainly made up of Elaeis guineensis parklands and Elaeis-Anacardium mosaic. These two units occupied respectively $31.2 \%$ and $35.4 \%$ of the total area. However, these two land-use units gradually gave way to pure Anacardium occidentale plantations. Indeed, 161.7 ha originally covered by palm groves are being transformed into cashew plantations in 2019. The Anacardium occidentale plantations, increased by 277.3 ha. In 2019, they correspond to the dominant cover with $31.7 \%$ of the Ponta Campo village land area. The mosaics (Elaeis-Anacardium) have also decreased by 210 ha. This situation is explained by the fact that these mosaics constitute a transition phase from parklands to cashew nut plantations.

During this period, cultivation areas also increased by 67.1 ha. These also constitute a transitional phase in the process of conversion of spaces. In most cases, the growing areas are just a pretext to aerate the space and promote the development of Anacardium seedlings.

\section{Evolution of the landscape units of the Ponta Pedra village terroir}

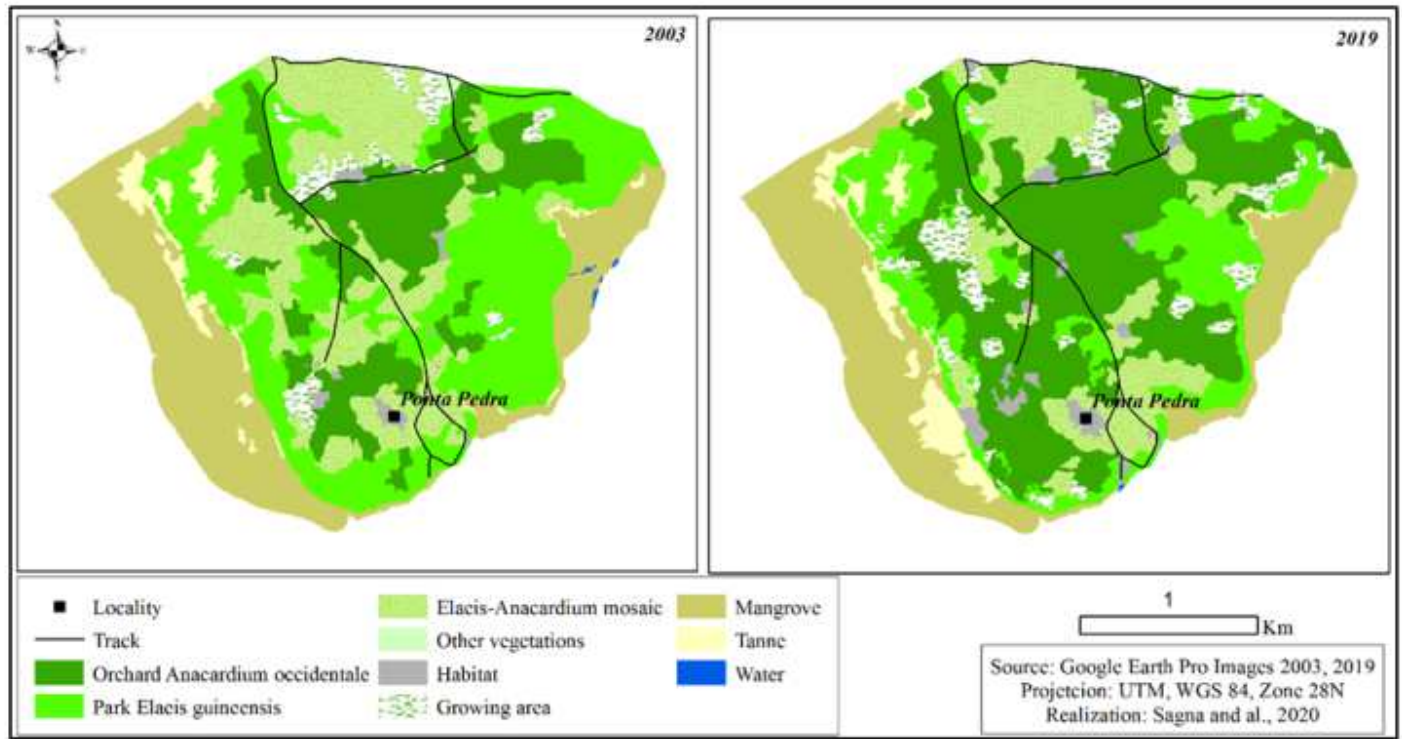

Figure 7. Mapping of the evolution of the landscape units of the village land of Ponta Pedra.

In the village of Ponta Pedra, the Elaeis guineensis parklands have undergone a very strong modification. This one is also marked by a conversion of the natural spaces in cashew plantation. The following figure shows the statistics

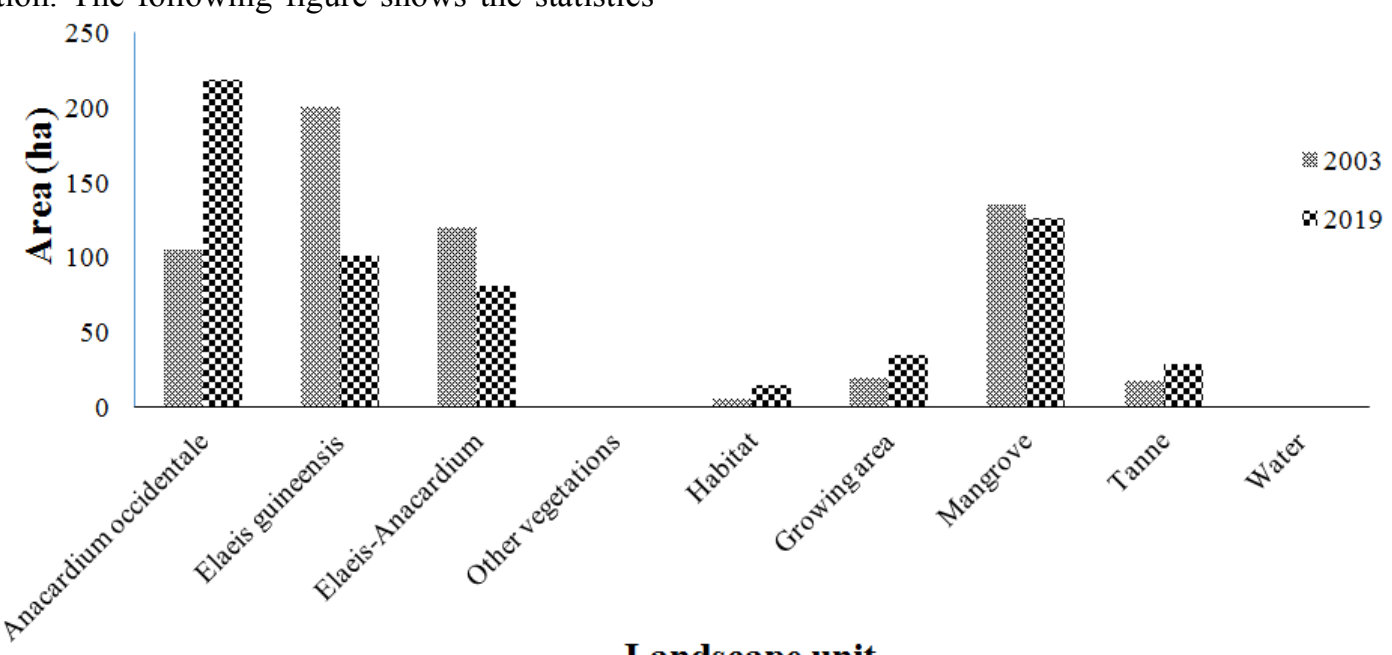

\section{Landscape unit}

Figure 8. Evolution of the surface areas of the landscape units of the Ponta Petra village terroir between the years 2003 and 2019.

The vast expanses of Elaeis guineensis Parklands that used to occupy $33.2 \%$ of the total area of Ponta Pedra have gradually disappeared in favour of cashew nut plantations.
In fact, a regression of 99.8 ha of Elaeis guineensis Parklands was noted between 2003 and 2019, compared to an increase of 113.9 ha of cashew nut plantations. The 
Elaeis guineensis Parklands, which were the dominant cover in 2003 with $33.2 \%$ of the study area, occupies only $16.7 \%$ in 2019. Similarly, the Elaeis-Anacardium mosaics have decreased by 99.8 ha. It must therefore be admitted that in this terroir, the first phase of transition from Parklands to Elaeis guineensis to Elaeis-Anacardium mosaics has been completed. And that the second phase, namely the transition from the mosaics to the pure Anacardium occidentale orchards, has begun. As for the cultivation areas, they have timidly increased by 15.3 ha and represent in $2019,5.8 \%$ of the village land area. On the other hand, the natural forests have almost disappeared.

\section{Evolution of the BucucurVillage Landscape Units}

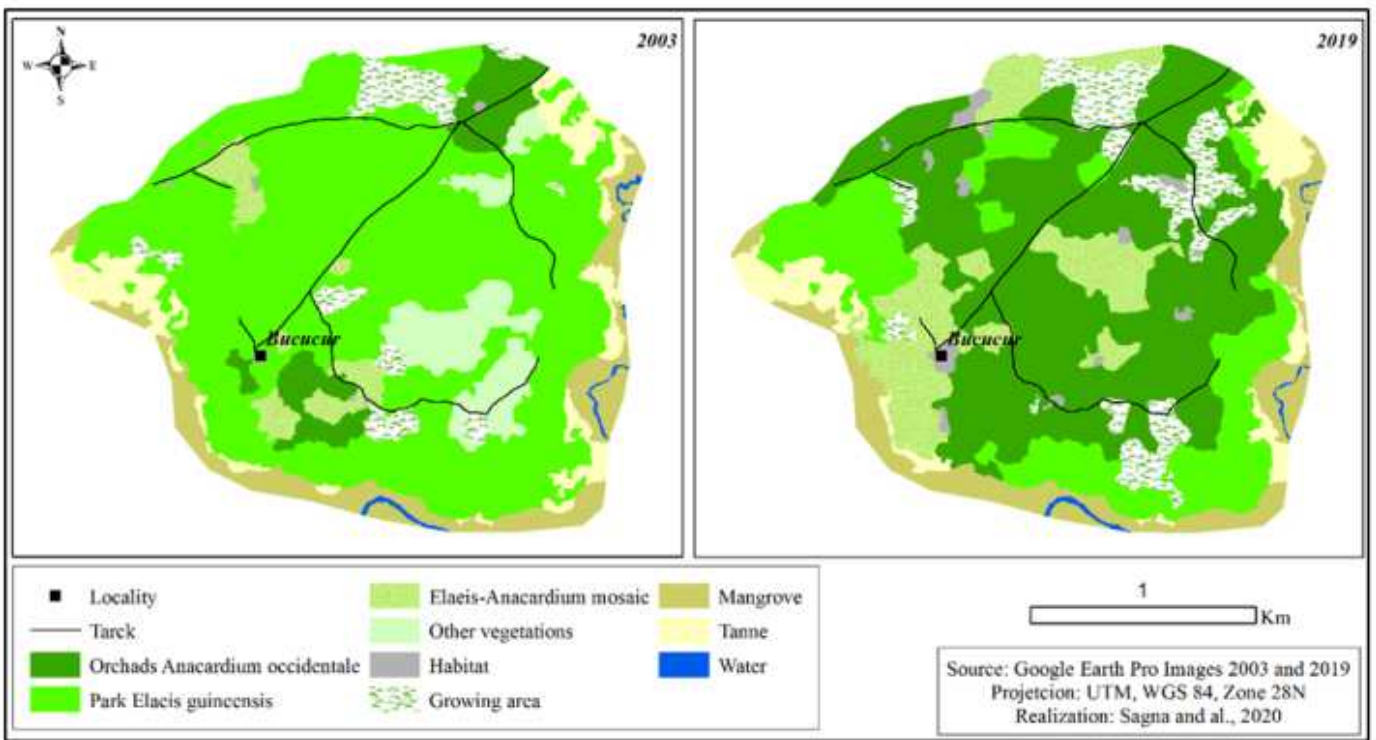

Figure 9. Mapping the evolution of the landscape units of the Bucucur village terroir.

Of all the village terroirs studied, Bucucur has experienced the greatest change in its landscape units, particularly the parklands at Elaeis guineensis, over the last 15 years. The Elaeis guineensis parklands have been almost entirely occupied by the Elaeis guineensis, which have unfortunately decreased in the area in favour of Anacardium occidentale plantations. This decrease has occurred at a very rapid rate. The evolution of the areas of the landscape units is shown in the following figure.

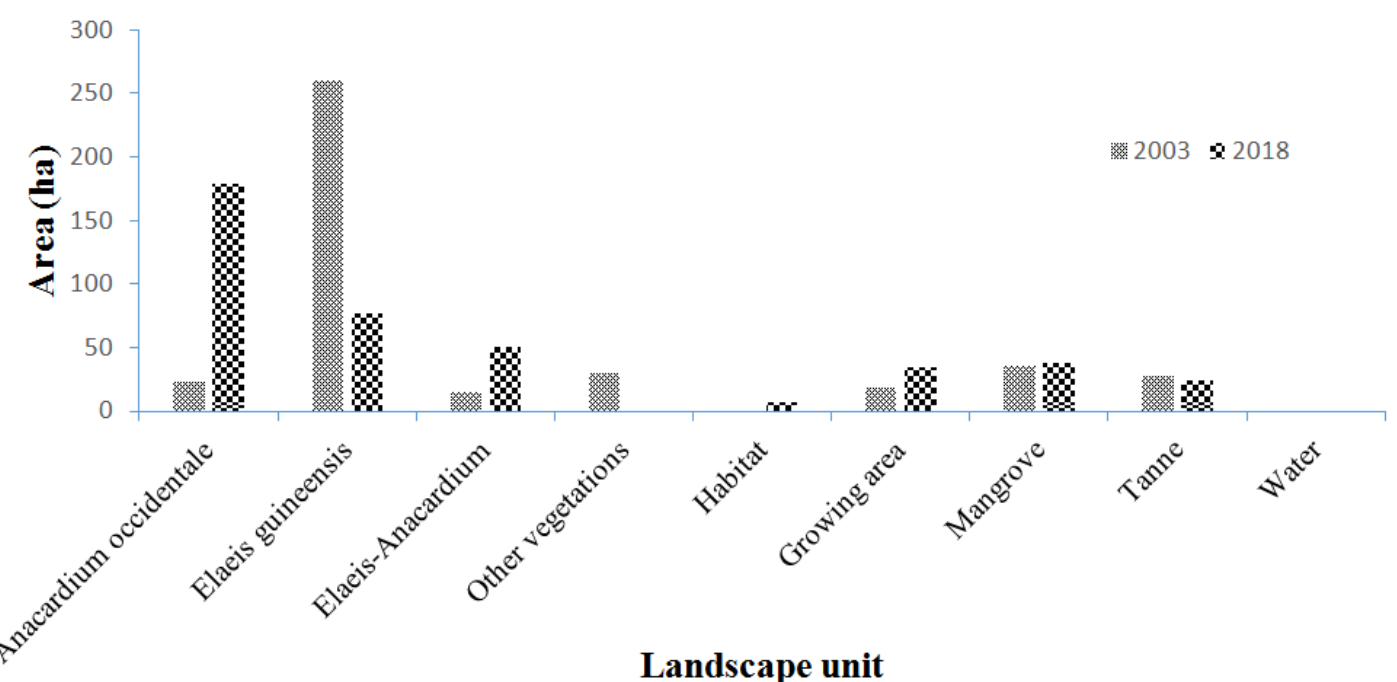

Figure 10. Evolution of the surface areas of the landscape units of the Bucucur village terroir between the years 2003 and 2019.

Bucucur's village terroir lost a very large part of its parklands in Elaeis guineensis between 2003 and 2019. This loss is 183 ha. In 2019 , the parklands occupy only $18.7 \%$ of the total area of the village land. Whereas in 2003, they were the dominant cover with $63.1 \%$ of the total area. This area is fully converted into pure Anacardium plantation (with 156.4 ha) and mosaic (with 35.6 ha of the area in 2019). These two landscape units represent respectively $43.4 \%$ and $12.3 \%$ of the village land. Cultivated areas have also increased by 16.4 ha. There is no natural forest left in the area. 


\section{Evolution of the landscape units of the Benocle village terroir}

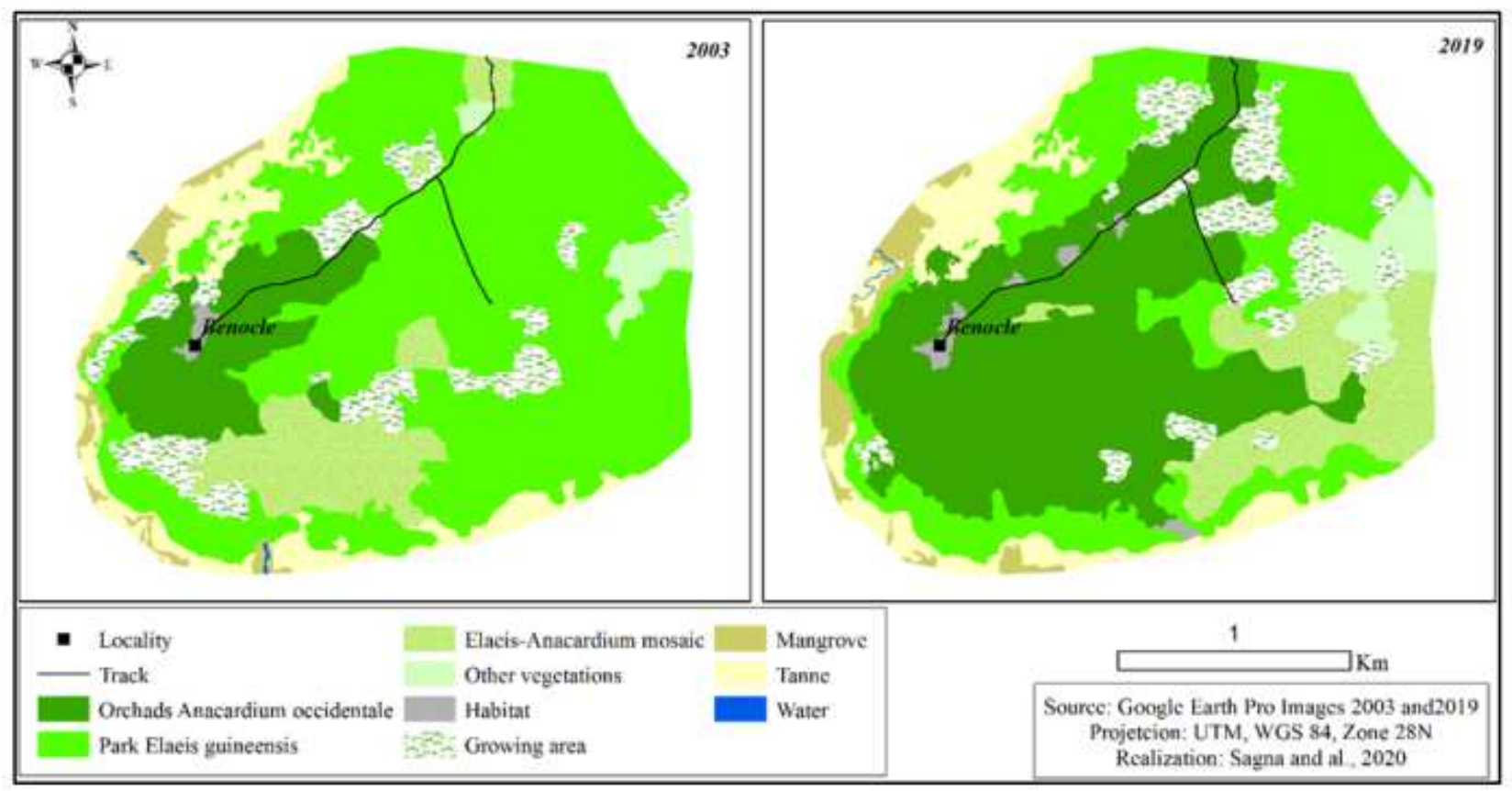

Figure 11. Mapping the evolution of the landscape units of the Benocle village terroir.

Like the previous village terroirs, in the Benocle terroir, the same trend, the progression of Anacardium occidentale plantations to the detriment of Elaeis guineensis parklands are noted. The degree of transformation of these classes is shown in the following figure.

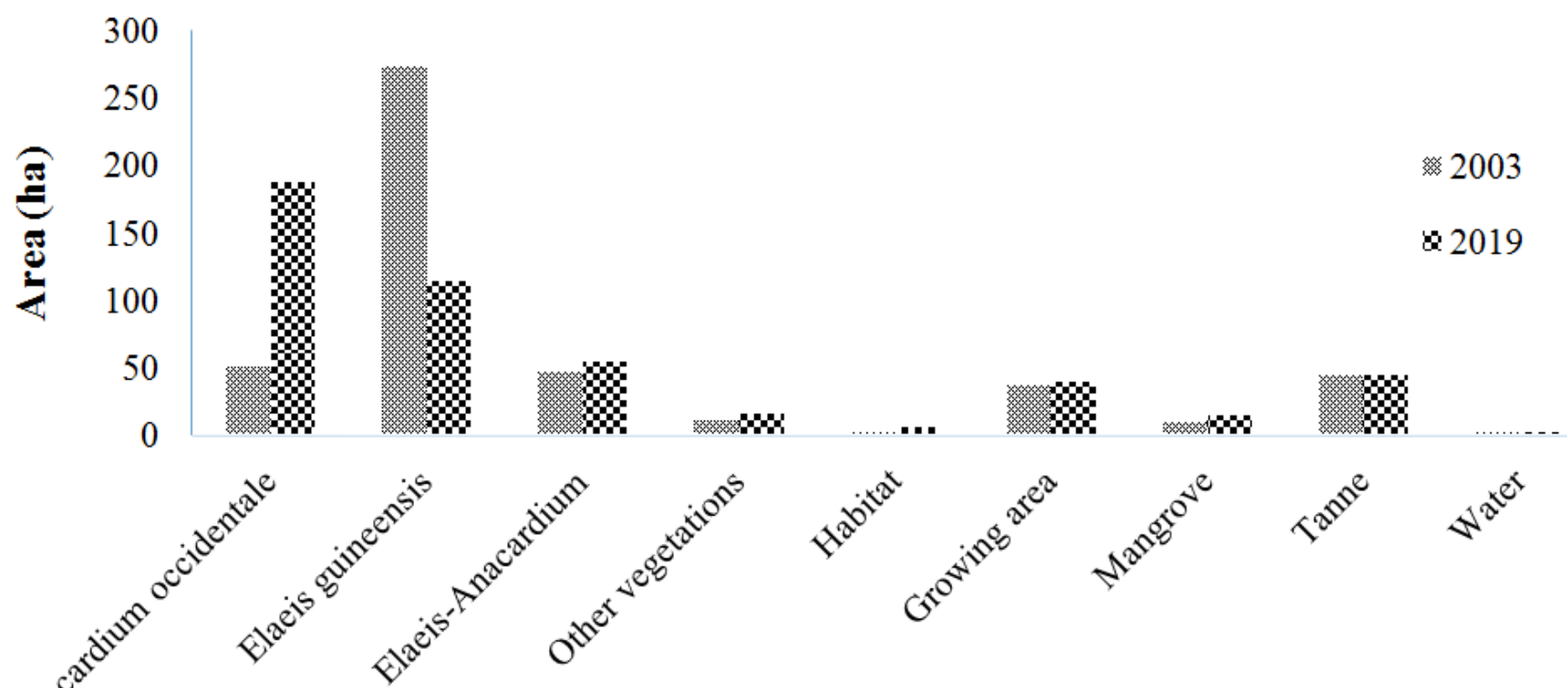

\section{Landscape units}

Figure 12. Evolution of the surface areas of the landscape units of the Benocle village terroir between 2003 and 2019.

Between 2003 and 2019, the Elaeis guineensis parklands lost 159.2 ha of their area, from 272.3 ha or $57.8 \%$ to 113.1 ha or $24 \%$. While cashew nut plantations increased by 136.8 ha and Elaeis-Anacardium mosaics by 7.6 ha. Natural vegetation increased from 10.6 ha to 15.6 ha, that to say an increase of 5 ha on the areas initially occupied by the parklands. These surfaces not yet coveted also constitute a transition towards cashew nut plantations. The areas under cultivation have evolved by only 1.8 ha. 


\section{Evolution of the landscape units of the Mpakaque village terroir}

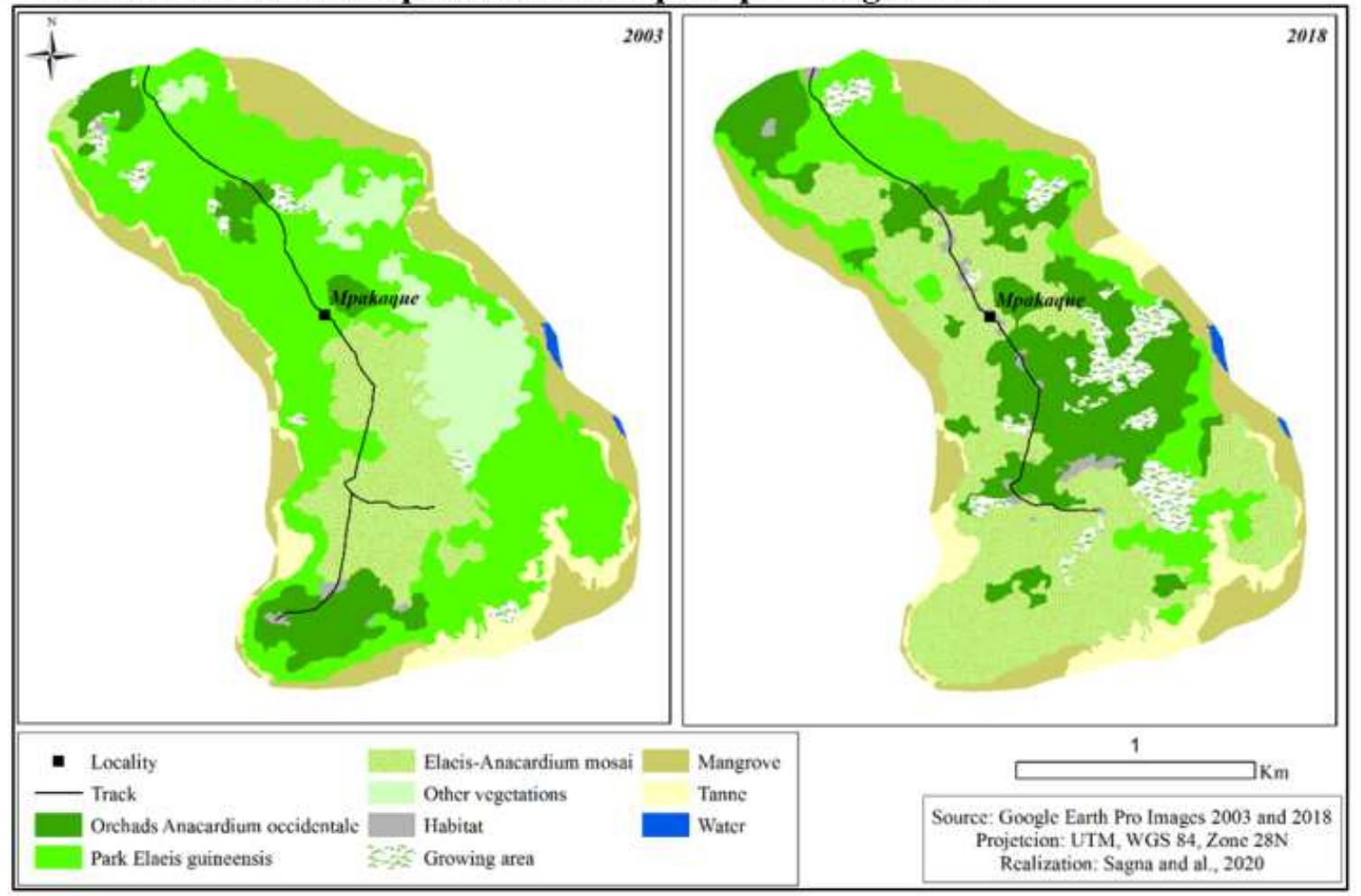

Figure 13. Mapping the evolution of the landscape units of the Mpakaque village terroir.

The village terroir of Mpakaque is undergoing a strong and recent transformation. A large part of the terroir is made up of orchards of pure Anacardium occidentale and mosaic. The latter is gradually increasing to the detriment of the other landscape units. The terroir is also characterized by the movement of the population from the south (2003) to the centre (2018). This situation, accompanied by a lack of monitoring of young plantations, has led to a halt in the development of cashew nut in this southern part and its substitution in mosaic. The degree of evolution of the different landscape units is recorded in the following figure.

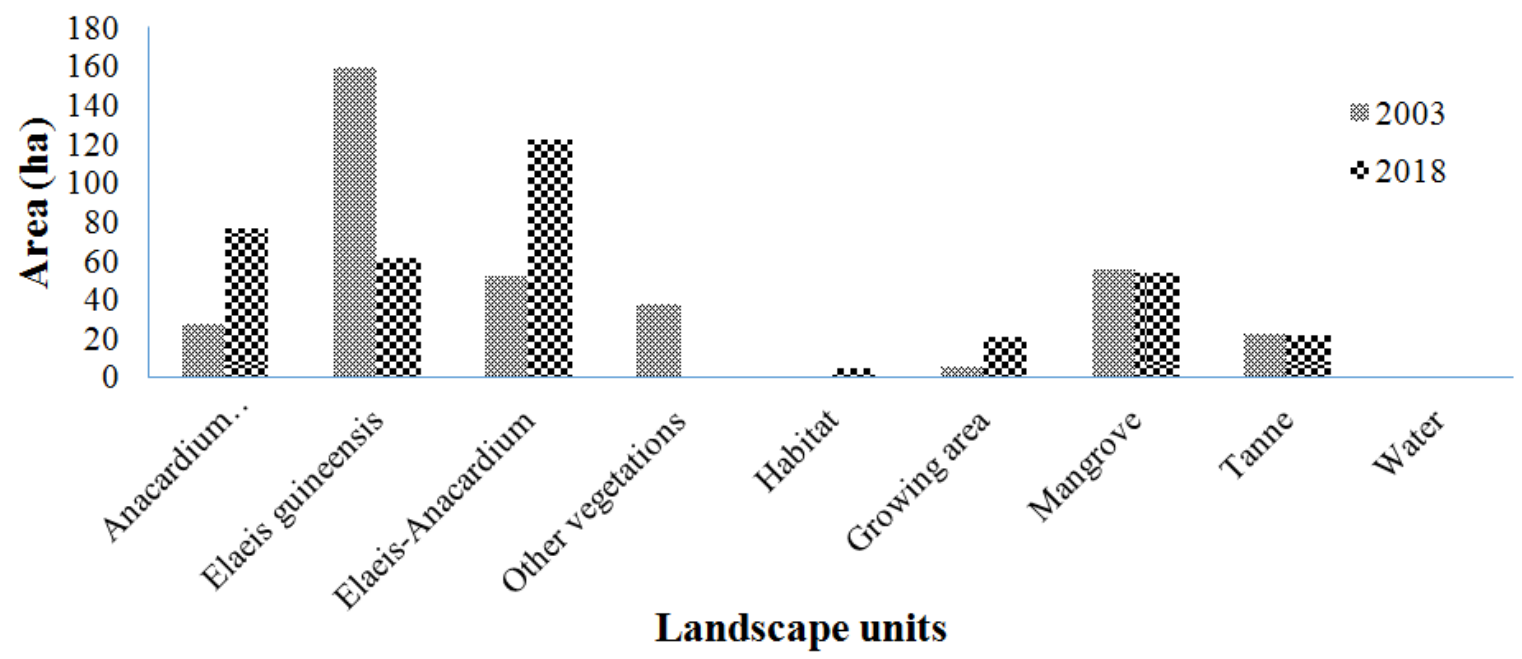

Figure 14. Evolution of the surface areas of the landscape units of the Mpakaque village terroir between the years 2003 and 2018.

The parklands in Elaeis guineensis represented $44 \%$ of the terroir in 2003. However, over an interval of 15 years, 98.5 ha of the land disappeared from the Elaeis guineensis parklands. Similarly, the natural vegetation has lost 37.9 ha of its surface area. The orchards of Anacardium occidentale have changed by 49.5 per cent and the mosaics by 69.9 per cent. The inhabited area is also undergoing a strong evolution with an increase of 3.2 ha during the same period. 


\section{Evolution of the landscape units of the village terroir of Djita centro}

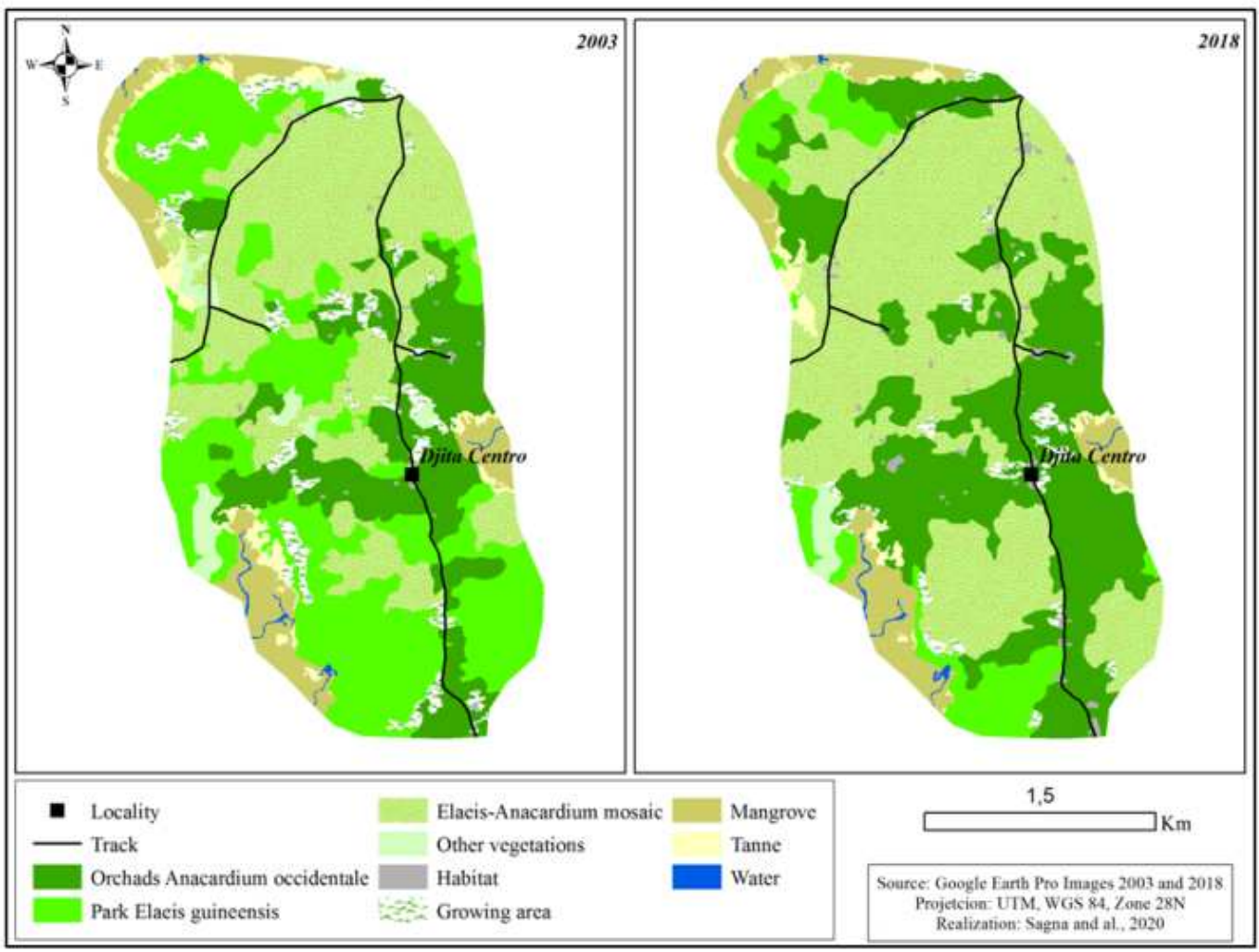

Figure 15. Cartography of the evolution of the landscape units of the village land of Djita Centro.

The village terroir of Djita centro is not spared by the transformation of natural landscape units into agrosystems. Indeed, as in all the sites studied, there is a strong increase in the surface area of Anacardium occidentale to the detriment of other landscape units. The following figure shows the intensity of the change in land use classes between the two years of the survey.

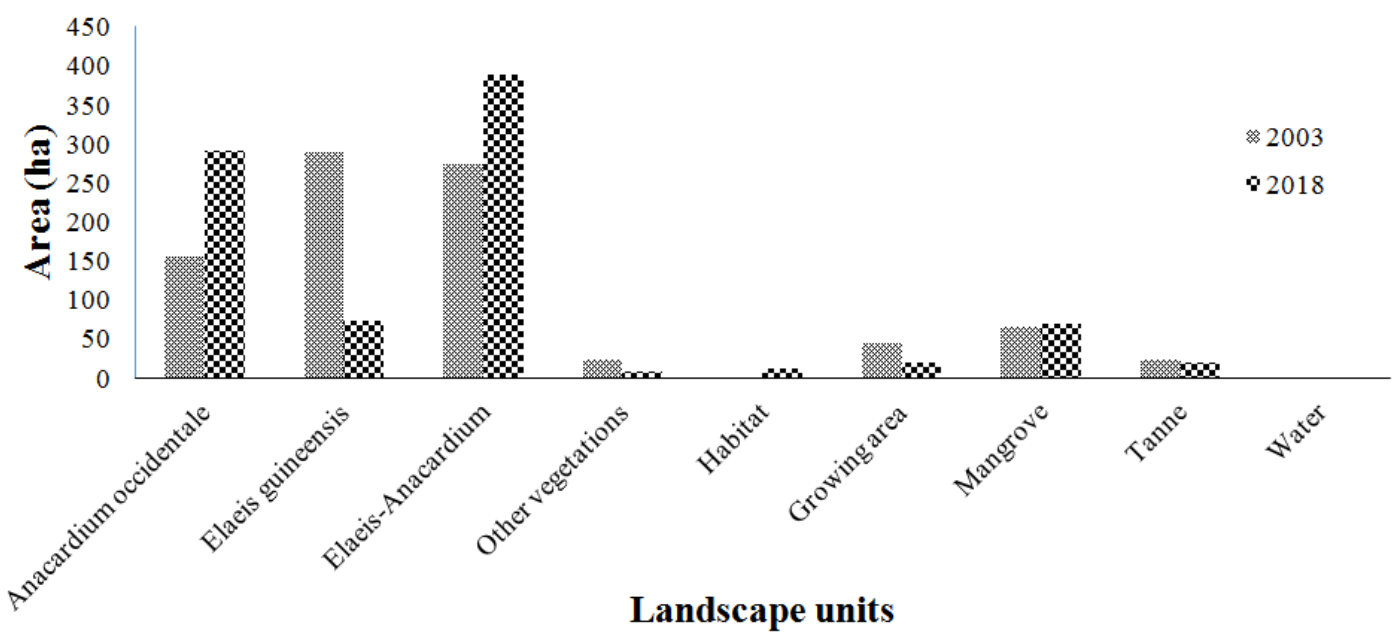

Figure 16. Evolution of the surface areas of the landscape units of the village land of Djita Centro between the years 2003 and 2018.

In the terroir of Djita centro, the Elaeis guineensis parklands have lost 217.4 ha. They occupy only $8.2 \%$ of the study area in 2018. On the other hand, Anacardium occidentale plantations have increased by 259.1 ha, including 136.1 ha of adult orchards and 115.8 ha of young plantations. Natural vegetation only represents $1 \%$ of the land, that to say 8.50 ha.

In general, there is a strong and progressive conversion of the Elaeis guineensis parklands and natural vegetation of the Cacheu region into a cultivation area and then into a Anacardium occidentale orchard, passing through the transitional mosaic phase. Residential areas are also expanding there. The general assessment of the evolution of land use classes in the study sites over the last 15 years is summarized in Table 2. 
Table 2. General assessment of the evolution of land use classes in hectares in the Study Sites between 2003 and 2019: values preceded by a minus sign (-) show an regression.

\begin{tabular}{lllllll}
\hline Land use class & Ponta campo & Ponta Pedra & Bucucur & Benocle & Mbackaque & Djita centro \\
\hline Anacardium occidentale plantation & 277,3 & 113,9 & 156,4 & 136,8 & 49,5 & 136,1 \\
Elaeis guineensis Parkland & $-161,7$ & $-99,8$ & -183 & $-159,2$ & $-98,5$ & $-217,4$ \\
Mosaic Elaeis-Anacardium & -210 & $-38,7$ & 35,6 & 7,6 & 69,9 & 115,8 \\
Other vegetations & 22,4 & -1 & $-29,6$ & 5 & $-37,9$ & $-14,6$ \\
Habitat & 4,5 & 8,8 & 5,5 & 3 & 3,2 & 8,2 \\
Growing area & 67,1 & 15,3 & 16,4 & 1,8 & 15,2 & $-25,7$ \\
Mangrove & 5,4 & $-8,7$ & 2,6 & 4,5 & $-1,3$ & 2,3 \\
Tanne & $-5,8$ & 10,7 & $-3,4$ & 0,5 & $-0,1$ & $-4,9$ \\
Water & 0,8 & $-0,4$ & $-0,5$ & 0 & 0 & 0,2 \\
\hline
\end{tabular}

\subsection{Causes of Elaeis guineensis Parklands Regression}

The sharp decline in Elaeis guineensis parklands noted in the Cacheu region is mainly related to a combination of the following anthropogenic and natural factors.

\subsubsection{Poor Agricultural Practices}

Like other forest resources, the Elaeis guineensis parklands are facing a constant degradation due to the current pejorative practices marked by a land tenure that encourages a race to monoculture cashew tree as a marker tree of the land (Figure 17). This monoculture has led to a strong conversion of natural parklands to cashew tree plantations. Indeed, there is a very large number of oil palm trees that are cut down annually for cashew plantations and for the cultivation of upland rice. Some producers go further by destroying the growth meristem of the young trees. In addition, the few individuals spared during clearing are either killed by the intense fires observed during burning operations or gradually smothered by cashew trees. Anacardium occidentale equidistance in plantations is very low. This equidistance is between 1 and $2 \mathrm{~m}$, which explains the high density and almost total coverage of the plots. Inventories carried out in Anacardium occidentale plantations have enabled an average of 2,462 individuals per hectare to be counted. Such conditions do not allow good growth of the palms, especially the young ones, which need sun and nutrients to live. They also contribute to the decrease in the productivity of palm groves in terms of wine and palm diets.

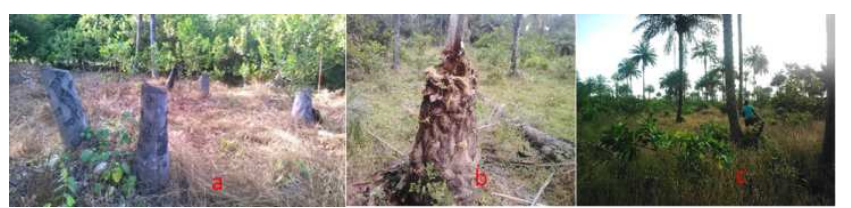

Figure 17. Conversion process of Elaeis guineensis parklands: (a and b) cutting of subject, (b) young plantation of Anacardium occidentale.

\subsubsection{Cuts for House Construction}

Borassus akeassii and Elaeis guineensis are the species whose stipes are mainly exploited in the construction industry for making ceilings and frames for houses. However, the former has almost disappeared in the region following a long period of over-exploitation. Thus Elaeis guineensis is almost the only one exploited for construction, increasing the pressure on the species. In fact, almost all the frames and roofs of the houses, in rural areas, are made with palm stipes and for each of them 15 to 25 or more palms are cut.
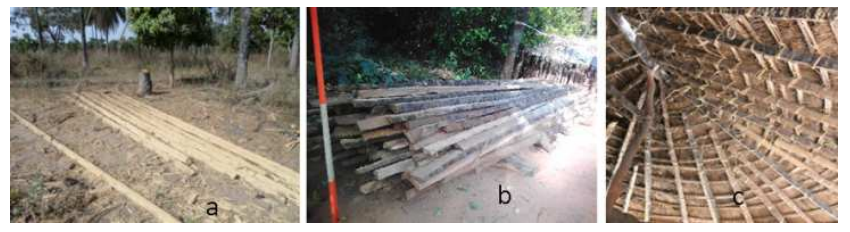

Figure 18. Use of Elaeis guineensis in Construction: (a) et (b) palm stipes, (c) Framework.

\subsubsection{Habitat Expansion}

In addition to the cutting of Elaeis guineensis subjects for the ceilings and the making of the frameworks, a not insignificant number is also cut, destoned to allow the establishment of the houses. It should be noted that many concessions or ponta are created with the advent of cashew.

\subsubsection{The Abusive Exploitation of Palm Wine}

The exploitation of wine is a highly developed economic activity in the region (Figure 19). It is either carried out by residents or operators from other regions of the country such as Oio and Biombo. The exploitation of wine, if it is carried out in accordance with the rules, allows the maintenance and sanitation of oil palm trees.

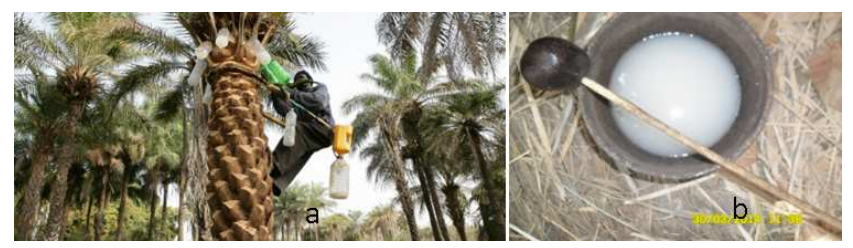

Figure 19. Exploitation of palm wine: (a) harvesting technique (b) palm wine.

However, certain techniques used by farmers, especially non-natives, lead to overexploitation and even death of many subjects. These include:

Farming on the same subject for a long time: productive palm trees can provide up to 20 litres of wine per day. However, if the duration of exploitation is too long (15 days), the subject ends up emptying its sap and dies afterwards.

Harvesting wine from the flowers: some people wish to start harvesting wine very early, starting with the flowers first and finishing with the bunches. This method makes the 
harvesting time very long and leads to the overexploitation and death of the palms.

Lack of maintenance of the palm trees: The nonexploitation of a palm tree due to the fact that many young people in the Cacheu region are no longer interested in bunching does not favour the development of the palm trees.

The use of foreign bodies to speed up the release of wine: to provoke an intense release of palm wine, some farmers push a large spike on the stipe after pruning the leaves. Others hammer all around the cleaned stipe to soften it or use mixtures of products such as those made from leaves of Moringa oleifera and Adansonia digitata to create heat around the trunk to accelerate the release of sap.

All these practices of palm wine harvesting, bad as they are, allow an abnormal increase in yield and also lead to the death of the palm trees. It is necessary to note that the exploitation of palm wine causes a decrease in the quality of the palm nuts. In fact, diets that have not been affected by the wine harvest produce better palm oil with a higher yield.

\subsubsection{Decreased Rainfall}

Palm groves are ecosystems that are generally located in transition zones. Thus, the many deficit years noted in recent decades often cause a long dry season leading to the advance of the salty tongue causing the death of some subjects.

\section{Discussion}

The Cacheu region is home to large tracts of wild oil palm forests. This variety adapts perfectly to the pedoclimatic conditions of the area. Compared to the improved variety commonly known as tenera, the wild variety is more resistant to logging practices and offers better quality products.

Parkland management in the region has evolved over time. The parklands in the village area belonged to the entire resident community and everyone could operate as they wished. However, there has been a gradual privatization of the parklands since the early 1980s. According to [18, 4], these years are marked by an unorganized race for land by villagers through cashew tree plantations, considered as a marker tree of the land, following an increase in land subsidies to commercial farmers or "ponteiros" by government authorities. As soon as gold, any palm grove located in a cleared area automatically becomes private property and its exploitation is exclusively reserved for the owner. This mode of management is found in the department of Oussouye (Lower Casamance) where each family has a land whose boundaries are well known to the entire community and where all the land is distributed and exploited by family members according to the rules of traditional land law [6]. Today, there are no collective or community parklands left in the village areas studied, except in a few places along the rivers, which are not suitable for cashew tree cultivation because of soil and water conditions.

As in all other parts of Guinea Bissau, the Cacheu region is marked by a very sharp reduction in the area of Elaeis guineensis parklands and an almost total disappearance of natural vegetation. This is mainly due to poor agricultural practices marked by a strong and progressive conversion of palm groves to cashew tree orchards. Between 2003 and 2018 , an average increase of 224 ha of cashew tree plantation per village terroir was noted, already causing the disappearance of 153.26 ha of Elaeis guineensis parklands on average. In order to plant cashew tree seedlings, a very large number of palm trees are cut down and burnt during the clearing of the land. In addition to this, the intensity of the preparatory work for the nut campaign and the almost total recovery due to the high density of cashew trees does not allow the development of Elaeis guineensis subjects, especially regeneration. The same observation was made by [14] according to which, the clearing of the vegetation cover for cashew nut monoculture is occupying more and more surfaces to the detriment of natural forests and areas of food crops. This is gradually leading to a decrease in forest cover.

Cuts for house construction accelerated by the expansion of housing, especially the new agricultural concessions (built thanks to cashew tree cultivation) are also one of the causes of the regression of palm groves. This is what leads $[7,8]$ to think that if nothing is done to rationalize the exploitation of the rônier and the palm tree, it is predicted that other building materials will have to be used. This is not the best scenario because of the country's financial limitations and the widespread degradation of forest vegetation in West Africa. According to the [13], selective logging is an activity that has contributed significantly to the depletion of resources.

In addition to this, there are poor practices in the exploitation of palm wine and climatic factors such as the drop in rainfall. This result confirms those of [2] according to whom, abusive cutting and climatic variability of recent decades with the corollary of salinization of land are the causes of regression of palm groves in Lower Casamance. It also corroborates $[11,10]$ who state that with the impact of drought and overexploitation of the subjects, natural palm groves have regressed in Lower and Middle Casamance. It also confirms [14] according to which, we are witnessing a degradation of renewable natural resources due to anthropic pressures aggravated by random climatic factors causing, among other things, the loss of biodiversity. As for [6], the palm stands in Casamance are generally regressive and the main causes of regression are the drop in rainfall, cuts for construction and the lack of maintenance of palm trees caused by the phenomenon of rural exodus of young people.

\section{Conclusion}

The Cacheu region contains important natural ecosystems, particularly the Elaeis guineensis agroforestry parklands, which contribute greatly to the well-being of the local population. The mode of governance of these parklands has evolved over time. They have moved from collective to private ownership. This privatization of the parklands is linked to the expansion of cashew nut plantations in the region. The analysis of the dynamics of the Elaeis guineensis agroforestry parklands in the region has led to the understanding that the 
disappearance of the Elaeis guineensis parklands and the natural vegetation is mainly linked to the uncontrolled expansion of cashew nut monoculture but also to cuts for construction, habitat expansion, poor harvesting practices and climatic deterioration. This reflects the intensity of pressure on the parklands despite their socio-economic importance. These parklands are at risk of disappearing if no action is taken to protect them. To this end, landowners must be made aware of the advantages of associating oil palm and cashew nuts in the same plot of land to diversify sources of income throughout the year. In order to better convince public opinion of the need to preserve the species, it is necessary to reinforce these results through an evaluation of the contribution of Elaeis Guineensis parklands to climate change mitigation. More specifically, it is a question of carrying out a study of the carbon storage capacity of these parklands.

\section{Acknowledgements}

This study was carried out within the framework of a partnership between the Research and Development Group for Rural Development (Grdr) and the Assane SECK University of Ziguinchor. This partnership is part of the broader framework of the Coastal Concerted Governance Program (PGCL). We would like to thank these two structures for their technical, material and financial support. We would also like to thank institutions such as the Laboratory of Plant Ecology of the University Cheikh Anta Diop of Dakar for his collaboration in the realization of the study. We also thank the populations of the villages chosen for the study for the reception, their availability, their collaboration during the collection of the data. Our thanks go to our relatives, wives and friends for their moral support.

\section{References}

[1] BOCK A., 2015. Diagnóstico sobre a situação de base da economia local na região de Cacheu: Oportunidades de mercado e de emprego para jovens e mulheres, constrangimentos e principais desafios. $68 \mathrm{p}$.

[2] CAMARA B. (2018). Caractérisation agro-écologique et socio-économique des parcs agroforestiers à Elaeis guineensis Jacq. et Faidherbia albida (del.) chev. et leurs influences sur la productivité du riz pluvial en basse Casamance (SENEGAL) Thèse de Doctorat en Agroforesterie, EDSTI/ Université Assane SECK /Ziguinchor, 153 pages.

[3] CAMARA A. A., DUGUE P., FORESTA H. (2012). Transformation des mosaïques de forêts-savane par des pratiques agroforestières en Afrique subsaharienne (Guinée et Cameroun), Cybergeo, $25 \mathrm{p}$.

[4] CATARINO L., MENEZES Y., SARDINHA R. (2015). Cashew cultivation in Guinea-Bissau - risks and challenges of the success of a cash. Sci. agric. (Piracicaba, Braz.) vol. 72 no. 5. p. 459-467.

[5] CSE. (2010). Évaluation des conditions et tendances des écosystèmes forestiers et de leurs services au Sénégal. Rapport final, Projet d'Amélioration et de Valorisation des Services des Écosystèmes Forestiers du Sénégal (PASEF), 244 p.
[6] DiATTA E. A. ET. SAGNA B. (2013). Caractérisation et modes d'exploitation des parcs à Elaeis guineensis, Jacq. en Basse Casamance: cas des villages de Carounate (cassa) et de Djiguinoume (kalounayes). Mémoire de Licence Agroforesterie, Université Assane de Ziguinchor. 49 pages.

[7] DIOMBERA K. (2003). La gestion des forêts tropicales secondaires en Afrique: Réalité et perspectives. Rapport National de la République de Guinée-Bissau. Atelier FAO/EC LNV/GTZ. 12 pages.

[8] DIOMBERA K. (1995). Rapport sur la conservation et l'aménagement durable des forêts en Guinée-Bissau. $10^{\circ}$ Session de la Commission des Forêts et de la Faune Sauvage pour l'Afrique, Sambonani (Afrique du Sud). 10 pages.

[9] GRDR. (2017). Le territoire de Cacheu: un immense potentiel, des actions en cours et des défis à relever. Monographie. Programme d'Appui au Développement Territorial en région de Cacheu (PADETEC). 116 pages.

[10] GUEYE S. (2000). Etude sur les ressources forestières et les plantations forestières du Sénégal, Période 1992-99, 61 pages.

[11] ILBOUdO J. B. ET SAMBOU B. (1991). -Facteurs de dégradation et restauration des palmeraies, séminaire atelier sur les barrages anti-sel et l'aménagement des terres basses. 59 pages.

[12] MANGA R. (2016). Entreprises cultuelles en région littorale: les pêcheurs d'hommes à Canchungo. $67 \mathrm{p}$.

[13] MINISTÉRIO DA AGRICULTURA E DESENVOLVIMENTO RURAL. (2010). Document de politique de developpement forestier. Version finale. 62 pages.

[14] PANA. (2006). Zona Costeira \& Pescas. Avaliação da Vulnerabilidade dos impactos, e as estratégias de adaptação. 31 p.

[15] SAGNA B. (2016). Situation de référence sur la filière huile de palme en région de Cacheu. Projet d'appui au développement d'une filière huile de palme durable en région de Cacheu (Guinée-Bissau). 44 pages.

[16] SARR M. A. (2009). Cartographie des changements de l'occupation du sol entre 1990 et 2002 dans le nord du Sénégal (Ferlo) à partir des images Landsat, Cybergeo. 26 pages.

[17] SCET INTERNATIONAL. (1978). Potentialités agricoles, forestières et pastorales en Guinée-Bissau- 3 vol. Fonds d'aide et de la coopération de la République française, Commisariat d'Etat à l'Agriculture et à l'Elevage. Commisariataux aux Ressources naturelles Bissau. 82 pages.

[18] SNUGB et UNDESA. (2010). Petits états insulaires en développement. 1er Rapport national sur la mise en œuvre de la stratégie de Maurice +5 . www.un.org/esa/dsd/dsd aofw sids/sids pdfs/msi plus5/nar/. 30/03/2017. 35 pages.

[19] TIXIER N., 2016. Le transect urbain. Pour une écriture corrélée des ambiances et de l'environnement. Sabine Barles; Nathalie Blanc. Écologies urbaines. Sur le terrain, EconomicaAnthropos; PIR Ville et Environnement, pp. 130-148.

[20] TIXIER N., AMPHOUX P., BUYCK J., TALLAGRAND D., 2016. Transect urbains et récits du lieu. Des ambiances au projet, in Xavier Guillot, coordination, Ville, territoires, paysage, actes du séminaire éponyme (Isle d'Abeau, mars 2015), Saint-Étienne, Publications Universitaires de SaintÉtienne, pp. 50-57. 